\title{
Temporal Variation of Nitrate and Phosphate in Selected Six Small Tanks of Dry Zone in Sri Lanka
}

\author{
W.M.G.D. Wijesundara, K.A. Nandasena ${ }^{1 *}$ and A.N.Jayakody ${ }^{1}$ \\ Postgraduate Institute of Agriculture \\ University of Peradeniya \\ Sri Lanka
}

\begin{abstract}
A tank cascade or a chain of tanks is a series of small reservoirs which is a unique irrigation system that flourished in the dry zone of Sri Lanka. The equilibrium state of a tank in relation to the water quality could be disrupted by intensive agriculture practices and human activities with growing population, resulting in artificial enriching these water bodies with various elements such as nitrogen, phosphorus and organic matter. Even though many hydrological studies have been conducted on dry zone tank cascade system, no systematic work, however, has been carried out on water quality aspects, particularly on the dynamics of nitrate $\left(\mathrm{NO}_{3}{ }^{-} \mathrm{N}\right)$ and phosphate $\left(\mathrm{PO}_{4}{ }^{3-}-\mathrm{P}\right)$ in tank water of the dry zone. The present study was conducted to evaluate the temporal variation of $\mathrm{NO}_{3}^{-}-\mathrm{N}$ and $\mathrm{PO}_{4}{ }^{3-}-\mathrm{P}$ in six selected tanks of two tank cascade systems viz. Thirappane and Mahakanumulla of the dry zone of Sri Lanka. $\mathrm{NO}_{3}^{-}-\mathrm{N}$ and $\mathrm{PO}_{4}^{3-}-\mathrm{P}$ of the tank water were analyzed in monthly intervals for one year starting from February 2010 to January 2011 using standard analytical techniques. According to the results, water in the six tanks of the two cascades exhibited a significant temporal variation during the twelve month-study period. Both cascades showed a bimodal pattern of nutrient fluctuation similar to the bimodal pattern of rainfall. $\mathrm{NO}_{3}^{-}-\mathrm{N}$ concentration of the six tanks varied from 1.41- $6.77 \mathrm{mg} / \mathrm{l}$. In the Maha season "dilution effect" caused by the large volume of water in the tanks due to heavy rainfall which may reduce the concentration of the soluble ionic species in tank water. Concentration of $\mathrm{PO}_{4}{ }^{3-} \mathrm{P}$ of the tank water of the six tanks of the two cascades also showed a significant temporal variation during the study period. Similar to the $\mathrm{NO}_{3}^{-}-\mathrm{N}$, concentration of $\mathrm{PO}_{4}{ }^{3-}-\mathrm{P}$ in tank water was high in the month of May in the Yala season while the lowest was recorded in the Maha season. Five tanks of the two cascade systems, especially, all three tanks of Mahakanumulla cascade showed high amounts of $\mathrm{PO}_{4}{ }^{3-}-\mathrm{P}$ over the EPA suggested value for eutrophication, in several months of the two seasons. In relation to the two nutrients studied, it can be recommended that waters of all tanks can be used for domestic needs and for irrigation as nutrient levels are less than the permissible level.
\end{abstract}

Key words: Nitrate, phosphate, tank water

\section{INTRODUCTION}

A tank cascade or a chain of tanks is a series of small reservoirs that are unique irrigation system flourished in the dry zone of Sri Lanka and some parts of Southern India and Thailand (Sakthvadivel et al., 1997; Shinogi, 2001). Undulating landform and the hard rock formation with shallow or moderately deep soil create ideal situation to construct small water storage tanks in the region. In this physical setting a large number of small tanks had been

* Department of Soil Science, Faculty of Agriculture, University of Peradeniya, Peradeniya, Sri Lanka

Author for correspondence: nandasenakalahe@y7mail.com 
constructed along the valleys. Annual variable low rainfall $(75 \%$ expectancy rainfall ranges $900-1400 \mathrm{~mm}$ ) combined with high annual evaporation rates create water scarcity affecting the livelihood of the people in the dry zone of Sri Lanka. Therefore, tanks are an important source of fresh water and help in replenishing ground water supplies (Dharmasena, 2005). It also provides habitat for numerous plants and animal species and helps to ease impacts of floods by storing large amounts of water, and droughts by releasing water during shortages.

The equilibrium state of tank in relation to the water quality could be disrupted by the intensive agriculture practices and human activities with growing population, artificially enriching the water bodies with elements such as nitrogen, phosphorus and organic matter. Accumulation of nutrient elements and organic matter which degrade the quality of water is called as eutrophication and is the principal threat to tank water quality resulting potential health hazard to humans (Young et al., 2010).

Even though many hydrological studies have been conducted by several researchers (Perera \& Piyasiri, 1999; Young et al., 2010) on dry zone tanks cascade system, no systematic work, however, has been carried out on water quality aspects particularly on the dynamics of $\mathrm{NO}_{3}{ }^{-}-$ $\mathrm{N}$ and $\mathrm{PO}_{4}{ }^{3-}-\mathrm{P}$ in tank water of dry zone. Further, the data available on the $\mathrm{NO}_{3}^{-}-\mathrm{N}^{-}$and $\mathrm{PO}_{4}{ }^{3-}-$ $\mathrm{P}$ accumulation in the water of the tank cascade system due to the intensive agriculture practices and human activities is very limited (Amarasri, 1973; Silva, 2004). Therefore, the objective of the present study was to evaluate the temporal variation of $\mathrm{NO}_{3}{ }^{-}-\mathrm{N}^{2}$ and $\mathrm{PO}_{4}{ }^{3-}-\mathrm{P}$ in selected six tanks of two tank cascade systems of the dry zone of Sri Lanka.

\section{MATERIALS AND METHODS}

Three tanks from Thirappane tank cascade (Meegasagama, Alisthana and Thirappane) and three tanks from Mahakanumulla cascade (Siwalagala, Amanakkatuwa and Maha kanumulla) located in Anuradhapura district, North Central Province were selected for this study.

Sampling had been carried out for one year from February 2010 to January 2011. Water samples were collected monthly intervals from three locations. There were three replicates for each analysis. Water samples were collected in clean plastic bottles and few drops of chloroform was added to prevent microbial growth. All the water bottles were brought to the Department of Soil Science, University of Peradeniya for analysis. All water samples were subjected to $\mathrm{NO}_{3}^{-}-\mathrm{N}$ and $\mathrm{PO}_{4}{ }^{3-}-\mathrm{P}$ analysis. $\mathrm{NO}_{3}{ }^{-}-\mathrm{N}$ and $\mathrm{PO}_{4}{ }^{3-}-\mathrm{P}$, of the water samples were measured using Sodium Salicylate (Markus et al., 1985) and Molybdate blue colorimetric procedures (Murphy and Riley, 1962) respectively.The rainfall, temperature and evaporation data were obtained from Maha Illuppalama meteorological station which is located $8 \mathrm{~km}$ from the experimental site. The data were analyzed statistically using SAS software package.

\section{RESULTS AND DISCUSSION}

\section{$\mathrm{NO}_{3}{ }^{-}-\mathrm{N}$ in the two tank cascade systems}

The results pertaining to $\mathrm{NO}_{3}{ }^{-} \mathrm{N}$ concentrations of water samples are given in Table $1 . \mathrm{NO}_{3}{ }^{-}-$ $\mathrm{N}$ concentration of water in the six tanks of two cascades showed a significant temporal variation (1.41-6.77 mg/l) during the twelve month study period. Maximum value of $\mathrm{NO}_{3}{ }^{-} \mathrm{-N}$ $(6.77 \mathrm{mg} / \mathrm{l})$ was recorded in Thirappane tank of the Thirappane cascade in the month of May 
2010. Lowest value $(1.41 \mathrm{mg} / \mathrm{l})$ was observed in the water of Siwalagala tank of the Mahakanumulla cascade during the month of September 2010. Both cascades showed a bimodal pattern of nutrient fluctuation similar to the bimodal pattern of monsoonal rainfall (Fig.1, 2 and 3).

Table 1. Temporal variation of $\mathrm{NO}_{3}^{-}-\mathrm{N}$ concentration $(\mathrm{mg} / \mathrm{l})$ in six tanks of Mahakanumulla $^{1}$ and Thirappane ${ }^{2}$ cascades from February 2010-January 2011.

\begin{tabular}{|c|c|c|c|c|c|c|c|c|c|c|c|}
\hline Tanks & Feb & Mar & April May & June & July & Aug & Sept & Oct & Nov & Dec & Jan \\
\hline Siwalagala & $2.37^{\mathrm{fg}}$ & $2.70^{\text {de }}$ & $3.21^{\mathrm{c}} 4.79^{\mathrm{a}}$ & $2.96^{\mathrm{cd}}$ & $2.56^{\mathrm{ef}}$ & $1.95^{\mathrm{h}}$ & $1.41^{i}$ & $2.34^{\mathrm{fg}}$ & $4.03^{\mathrm{b}}$ & $2.47^{\text {efg }}$ & $2.17^{\text {gh }}$ \\
\hline Amanakkatuwa ${ }^{1}$ & $2.79^{\mathrm{cd}}$ & $2.90^{\mathrm{c}}$ & $4.29^{\mathrm{b}} 5.41^{\mathrm{a}}$ & $5.67^{\mathrm{a}}$ & $2.91^{\mathrm{c}}$ & $2.44^{\mathrm{de}}$ & $1.90^{\mathrm{f}}$ & $2.87^{\mathrm{c}}$ & $4.37^{\mathrm{b}}$ & $2.84^{\mathrm{c}}$ & $2.34^{\mathrm{e}}$ \\
\hline Mahakanumulla $^{1}$ & $2.91^{\mathrm{f}}$ & $3.03^{\mathrm{f}}$ & $4.63^{\mathrm{d}} 6.76^{\mathrm{a}}$ & $6.39^{\mathrm{b}}$ & $2.71^{\mathrm{fgh}}$ & $2.54^{\mathrm{gh}}$ & $1.92^{\mathrm{i}}$ & $3.43^{\mathrm{e}}$ & $5.77^{\mathrm{c}}$ & $2.85^{\mathrm{fg}}$ & $2.40^{\mathrm{h}}$ \\
\hline Meegasagama $^{2}$ & $3.04^{\mathrm{f}}$ & $4.19^{d}$ & $4.64^{\mathrm{c}} 5.44^{\mathrm{a}}$ & $4.68^{\mathrm{c}}$ & $3.52^{\mathrm{e}}$ & $2.21^{\mathrm{g}}$ & $3.49^{\mathrm{e}}$ & $5.22^{\mathrm{b}}$ & $4.30^{\mathrm{d}}$ & $3.14^{\mathrm{f}}$ & $3.09^{\mathrm{f}}$ \\
\hline Alistana $^{2}$ & $3.36^{\mathrm{fg}}$ & $4.32^{\mathrm{e}}$ & $4.87^{\mathrm{d}} 5.96^{\mathrm{a}}$ & $4.96^{\mathrm{d}}$ & $3.64^{\mathrm{f}}$ & $2.43^{\mathrm{h}}$ & $3.55^{\mathrm{fg}}$ & $5.33^{\mathrm{c}}$ & $5.63^{\mathrm{b}}$ & $3.55^{\mathrm{fg}}$ & $3.30^{\mathrm{g}}$ \\
\hline Thirappane $^{2}$ & $3.49^{\mathrm{i}}$ & $4.48^{\mathrm{f}}$ & $5.11^{\mathrm{e}} 6.77^{\mathrm{a}}$ & $5.82^{\mathrm{c}}$ & $3.76^{\mathrm{g}}$ & $2.59^{j}$ & $3.57^{\mathrm{hi}}$ & $5.61^{\mathrm{d}}$ & $6.14^{\mathrm{b}}$ & $3.78 \mathrm{~g}$ & $3.69^{\mathrm{gh}}$ \\
\hline
\end{tabular}

*Means with same letters are not significantly different within the months

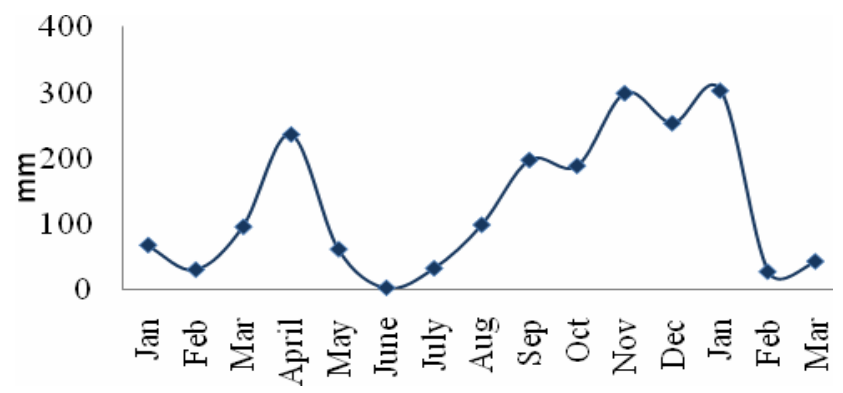

Fig. 1. Rainfall distribution pattern during February 2010-January 2011

In dry zone, there are two distinct seasons namely yala (low rainfall season) and maha (high rainfall season) based on the rainfall distribution. Yala and maha seasons fall in the months of April to September and October to March, respectively.

Rice is the main crop cultivated in the commanding areas of the tanks in both seasons. Fertilizers are applied at the months of April to May and October to November in yala and maha seasons, respectively. In the yala season, land preparation for the paddy cultivation is done in late April to early May and planting begins early weeks of May. In this period fertilizers are applied as basal and top dressings to the farm fields in the catchment area. With the intense rainfall in both seasons applied fertilizers, plant residues, cow dung and other animal excreta along with the soil sediments are being transported to the tanks through surface runoff and seepage of water (Bandara, 2007). As a result, the $\mathrm{NO}_{3}{ }^{-}-\mathrm{N}$ and $\mathrm{PO}_{4}{ }^{3-}-\mathrm{P}$ concentrations had been increased in tank waters corresponding to the two cultivation seasons (Fig 2, 3, 4 and 5). In this study, all the tanks showed highest amounts of $\mathrm{NO}_{3}{ }^{-} \mathrm{N}$ during the period of April to June which falls within the yala season of the dry zone. The high concentration of $\mathrm{NO}_{3}{ }^{-} \mathrm{N}$ in yala season could be further aggravated by the low water storage of the tanks due to the low rainfall $(900 \mathrm{~mm} / \mathrm{yr})$ and the high evaporation rate $(6$ $\mathrm{mm} /$ day) of the dry zone.

An increasing trend of $\mathrm{NO}_{3}{ }^{-} \mathrm{N}$ was observed in waters of Thirappane and Mahakanumulla tanks which are located in the lowest part of the two cascades (Table 1). Out of that, the 
highest accumulation was recorded in Thirappane tank. Immediate catchment of Thirappane tank is used as a dumping ground for garbage from a nearby town and also subject to frequent grazing by relatively large cattle population in large extent of the thaulla (land just above the tank).

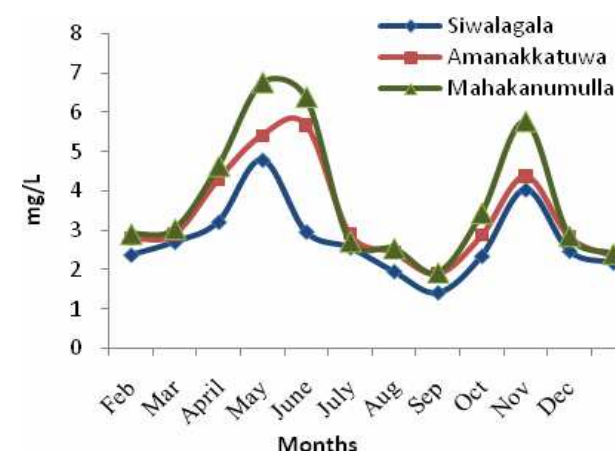

Fig. 2. $\mathrm{NO}_{3}{ }^{-} \mathrm{N}$ concentration in Mahakanumulla cascade

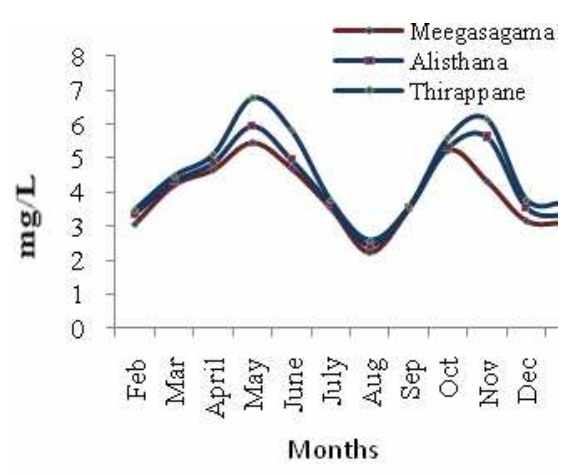

Fig. 3. $\mathrm{NO}_{3}^{-}-\mathrm{N}$ concentration in Thirappane cascade

Accumulation of cow dung and other animal excreta in large quantities may partly contribute to the high value of $\mathrm{NO}_{3}{ }^{-} \mathrm{N}$. However, the $\mathrm{NO}_{3}{ }^{-} \mathrm{N}$ concentration of six tanks of the two cascades did not exceed the permissible level which is $10 \mathrm{mg} / \mathrm{l}$ (WHO, 1984) for irrigation and drinking water quality. In the maha season "dilution effect" caused by the large volume of water in the tanks due to heavy rainfall may bring down the soluble ionic species concentration in tank water compared to the yala season. Therefore, it is certain that the $\mathrm{NO}_{3}{ }^{-}$ $-\mathrm{N}$ content of the water goes down due to the high volume of tank water.

\section{$\mathrm{PO}_{4}{ }^{3-}-\mathrm{P}$ in the two cascade systems}

Concentration of $\mathrm{PO}_{4}{ }^{3-}-\mathrm{P}$ of the tank water of six tanks of the two cascades was also showed a significant temporal variation during the study period (Table 2). Similar to the $\mathrm{NO}_{3}{ }^{-} \mathrm{N}$, concentration of $\mathrm{PO}_{4}{ }^{3-}-\mathrm{P}$ in tank water was high in the month of April in yala season while lowest was recorded in the maha season. The increasing trend of $\mathrm{PO}_{4}{ }^{3-}-\mathrm{P}$ in tank water was observed as two peaks corresponding to the two rainy seasons (Fig. 1, 4 and 5).

Table 2. Temporal variation of $\mathrm{PO}_{4}{ }^{3-}$-Pconcentration $(\mathrm{mg} / \mathrm{l})$ in six tanks of Mahakanumulla ${ }^{I}$ and Thirappanecascades $^{2}$ from February 2010-January 2011

\begin{tabular}{|c|c|c|c|c|c|c|c|c|c|c|c|c|}
\hline & Feb & March & April & May & June & July & Aug & Sep & Oct & Nov & Dec & Jan \\
\hline Siwalagala & $0.01^{\mathrm{cd}}$ & $0.01^{\mathrm{cd}}$ & $0.22^{\mathrm{a}}$ & $0.10^{\mathrm{b}}$ & $0.03^{\mathrm{c}}$ & $0.03^{\mathrm{cd}}$ & $0.01^{\text {cd }}$ & $0.01^{\mathrm{cd}}$ & $0.10^{\mathrm{b}}$ & $0.11^{\mathrm{b}}$ & $0.01^{\mathrm{cd}}$ & $.002^{\mathrm{d}}$ \\
\hline Amanakkatuwal & $0.01^{\mathrm{c}}$ & $0.02^{\mathrm{c}}$ & $0.35^{\mathrm{a}}$ & $0.23^{\mathrm{b}}$ & $0.05^{\mathrm{c}}$ & $0.03^{\mathrm{c}}$ & $0.02^{\mathrm{c}}$ & $0.02^{\mathrm{c}}$ & $0.18^{\mathrm{b}}$ & $0.18^{\mathrm{b}}$ & $0.07^{\mathrm{c}}$ & $0.003^{\mathrm{c}}$ \\
\hline MahaKanumulla & ${ }^{I} 0.02^{\text {ef }}$ & $0.38^{\mathrm{a}}$ & $0.39^{\mathrm{a}}$ & $0.30^{\mathrm{b}}$ & $0.07^{\mathrm{d}}$ & $0.06^{\mathrm{de}}$ & $0.07^{\mathrm{ef}}$ & $0.02^{\text {ef }}$ & $0.23^{\mathrm{c}}$ & $0.21^{\mathrm{c}}$ & $0.03^{\mathrm{ef}}$ & $0.002^{\mathrm{f}}$ \\
\hline Meegasagama $^{2}$ & $0.03^{\mathrm{abc}}$ & $0.03^{\mathrm{abc}}$ & $0.04^{\mathrm{ab}}$ & $0.04^{\mathrm{a}}$ & $0.01^{\mathrm{dc}}$ & $0.01^{\mathrm{d}}$ & $0.01^{\mathrm{dc}}$ & $0.01^{\mathrm{dc}}$ & $0.02^{\text {bdo }}$ & $0.02^{\text {bdc }}$ & $0.01^{\mathrm{d}}$ & $0.01^{\mathrm{d}}$ \\
\hline Alisthana $^{2}$ & $0.03^{b c}$ & $0.04^{\mathrm{b}}$ & $0.08^{\mathrm{a}}$ & $0.05^{\mathrm{b}}$ & $0.04^{\mathrm{b}}$ & $0.01^{\mathrm{de}}$ & $0.03^{\mathrm{bcc}}$ & $0.02^{\text {cde }}$ & $0.04^{\mathrm{b}}$ & $0.03^{\text {bcd }}$ & $0.02^{\text {cde }}$ & $0.006^{\mathrm{e}}$ \\
\hline Thirappane ${ }^{2}$ & $0.05^{\text {cde }}$ & $0.08^{\mathrm{b}}$ & $0.11^{\mathrm{a}}$ & $0.07^{\mathrm{bc}}$ & $0.06^{\prime}$ & $0.05^{\text {cde }}$ & $0.02^{\mathrm{fg}}$ & $0.02^{\text {efg }}$ & $0.07^{\mathrm{b}}$ & $0.04^{\mathrm{def}}$ & $0.03^{\mathrm{def}}$ & $0.007^{\mathrm{g}}$ \\
\hline
\end{tabular}

*Means with same letters aren't significantly different within the months

An increase of $\mathrm{PO}_{4}{ }^{3-}-\mathrm{P}$ was observed from the beginning of the two seasons. This was certainly due to the surface runoff of water to the tanks with the soil sediments enriched with 
the applied phosphate fertilizers in the recent catchment areas. The $\mathrm{PO}_{4}{ }^{3-}-\mathrm{P}$ is one of the major macro nutrients which are responsible for the eutrophication of tank water. During the study period, similar to $\mathrm{NO}_{3}{ }^{-} \mathrm{N}$, the highest $\mathrm{PO}_{4}{ }^{3-}-\mathrm{P}$ values were observed during yala season. The $\mathrm{PO}_{4}{ }^{3-}-\mathrm{P}$ concentration of six tanks ranged between $0.007-0.39 \mathrm{mg} / \mathrm{l}$, where the highest value was recorded in April 2010 in Mahakanumulla tank and the lowest value was observed in January 2011, in Thirappane tank.

$\mathrm{PO}_{4}{ }^{3-}-\mathrm{P}$ concentration in tank water generally showed a little variation. The critical level for $\mathrm{PO}_{4}{ }^{3-}-\mathrm{P}$ for occurrence of eutrophication in tanks is $0.08 \mathrm{ppm}$ (EPA, 1988). Higher $\mathrm{PO}_{4}{ }^{3-}-\mathrm{P}$ concentrations than the EPA standard were observed in water of tanks of Mahakanumulla cascade during some months (March, April, May, October and November) in both seasons.

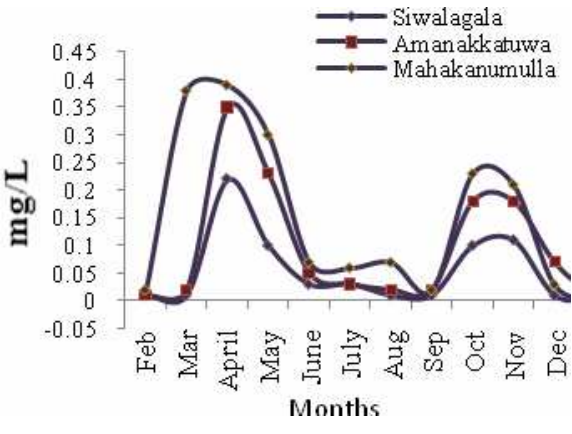

Fig. 4. $\mathrm{PO}_{4}{ }^{3-}$-Pconcentration in Mahakanumulla cascade

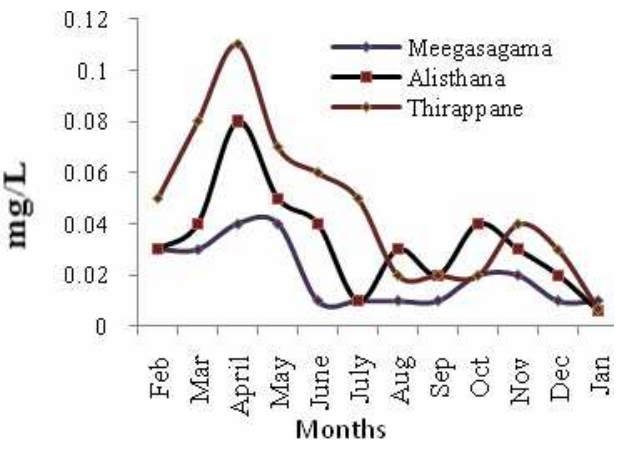

Fig. 5. $\mathrm{PO}_{4}{ }^{3-}$-Pconcentration in Thirappane cascade

This may be due to the specific physical setting of the Mahakanumulla cascade which is a branch type and has a large extent of catchment area compared to the Thirappane cascade. Therefore, there is a possibility for occurrence of eutrophication in the future due to the enrichment of $\mathrm{PO}_{4}{ }^{3-}-\mathrm{P}$ in tank waters of the Mahakanumulla cascade.

\section{CONCLUSIONS}

Both cascades showed a bimodal pattern of nutrient fluctuation similar to the bimodal pattern of monsoonal rainfall. $\mathrm{NO}_{3}^{-}-\mathrm{N}$ concentration of water in the six tanks of two cascades showed a significant temporal variation during the twelve month study period. It was varied from 1.41-6.77 mg/l. With the intense rainfall, applied fertilizers, crop residues, cow dung and other animal excreta along with the soil sediments are being transported through the surface run off and accumulated in the tanks resulting in increased concentrations of $\mathrm{NO}_{3}{ }^{-} \mathrm{N}$ and $\mathrm{PO}_{4}{ }^{3-}-\mathrm{P}$ in tank water. The high concentrations of $\mathrm{NO}_{3}^{-}-\mathrm{N}$ and $\mathrm{PO}_{4}{ }^{3-}-\mathrm{P}$ in yala season could be further aggravated by the low water storage of the tanks due to the low rainfall $(<900 \mathrm{~mm} / \mathrm{yr})$ and the high evaporation rate $(6 \mathrm{~mm} /$ day $)$ during months of the dry zone. In the maha season "dilution effect" caused by large volume of water in the tanks due to heavy rainfall may bring down the soluble ionic species concentration in tank water. Concentration of $\mathrm{PO}_{4}{ }^{3-}-\mathrm{P}$ of the tank water of six tanks of the two cascades was also showed a significant temporal variation during the study period. Similar to the $\mathrm{NO}_{3}{ }^{-} \mathrm{N}$, concentration of $\mathrm{PO}_{4}{ }^{3-}-\mathrm{P}$ in tank water was high in the month of May in yala season while the lowest was recorded in the maha season. Five tanks of the two cascade system, especially all three tanks of Mahakanumulla cascade, showed high mounts of $\mathrm{PO}_{4}{ }^{3-}-\mathrm{P}$ over the EPA suggested value for 
eutrophication in several months of the two seasons. In relation to two nutrients studied, it can be recommended that waters of all tanks can be used for domestic needs and for irrigation as nutrient levels are less than the permissible level.

\section{REFERENCES}

Amarasiri, S.L. (1973).Water Quality of Major Irrigation Tanks in Sri Lanka. Trop.Agri., CXXIX: 19-25.

Bandara, J.M.R.S (2007). Nature farming, Integration of traditional knowledge system with modern farming in rice.pp.21-22 AB Leusden, Netherlands.

Dharmasena, P.B. (2005). Traditional village tank system for conservation and effective use of water. Paper presented at the International Seminar on 'Management of Large-Scale Irrigation System for Better Conservation and Use of Water Resources' 12-17 September 2005 - Colombo, Sri Lanka

EPA, (1988). The Lake and Reservoir Restoration Guidance Manual. EPA 440/5.88.002.EPA criteria and standards divisionnon-point sources branch. Washington, D.C.20460.

Markus, D.K., McKinnon, J.P. and Buccafuri, A.F. (1985). Automated analysis of nitrite, nitrate and ammonium nitrogen in soils. Soil Sci. Soc. of America j. 49, 1208-1215.

Murply, J. and Riley, J.P. (1962). Anal.Chem.Acta.27-31 In: Hesse, P.R. (ed.). A text book of Soil Chemical analysis, John Murray (publishers) Ltd. London.

Perera, N. and Piyasiri, S. (1999). Species composition and population dynamic of photo plankton community in Kothmale reservoir. J. Nat. Sci. Council, Sri Lanka, 1998 (26) 4,293309.

Sakthivadivel, R., Fernando, N. and Brewer, J.D. (1997). Rehabilitation planning for small tanks in cascades: A methodology based on rapid assessment.13 Research Report. International Irrigation Management Institute, Colombo.

Shinogi, Y. (2001). Optimal water management of tank cascade system, International commission on Irrigation and Drainage $1^{\text {st }}$ Asian Regional Conference.

Silva, E.I.L. (2004). Water quality in Sri Lanka-status and trends. Asian J. of Water, Environ. and pollution, $1(182), 9-12$.

WHO, (1984). Guideline for drinking water quality, Vol. 1 and 2.Geneva: World Health Organization

Young, S.M, Pitawala, A. and Gunathilaka, J. (2010). Fate of phosphate and Nitrate in waters of an intensive agricultural area in the Dry Zone of Sri Lanka. Paddy Water Environ. 8,71-79. 